\title{
La dimensión pneumatológica de la Iglesia según Ireneo de Lyon
}

\author{
Alejandro E. Nicola \\ INSTITUTO TEOLÓGICO CÓRDOBA, ARGENTINA
}

\section{INTRODUCCIÓN}

En un primer acercamiento a la obra de Ireneo de Lyon se puede percibir el marcado acento puesto en el elemento pneumatológico y también en la valoración de la dimensión eclesial. Sobre la teología de San Ireneo se han escrito muchas y bellas páginas ${ }^{1}$. Existen algunos estudios que han profundizado en la pneumatología del $s^{2} t^{2}$, pero su eclesiología considerada globalmente no ha sido objeto de muchos trabajos ${ }^{3}$. En cambio, son abundantes las investigaciones realizadas sobre el tema de la Tradición en la Iglesia, la sucesión apostólica y el primado de la Iglesia de Roma ${ }^{4}$. Sin embargo, sobre la relación Iglesia-Espíritu Santo en par-

1 Cf. A. Orbe, Antropología de San Ireneo (Madrid 1969), 3.

2 Cf. A. D’AlÈs, «La Doctrine de l'Esprit en Saint Irénée» en Recherches de Science Religieuse 6 (1924), 497-538; H.J. JasCKe, Der Heilige Geist im Bekenntnis der Kirche. Eine Studie zur Pneumatologie des Irenäus von Lyon im Ausgang vom altchristlichen Glaubensbekenntnis (Münster 1976); A. Orbe, «La teología del Espíritu Santo» en Estudios Valentinianos IV (Roma 1966).

3 Entre los más clásicos: W. Schmidt, Die kirche bei Irenäus (Helsingfors 1934); G. BARdy, La Théologie de l' Église de saint Clément de Rome à saint Irénée (Paris 1945), 183-210; G. Jossa, Regno di Dio e Chiesa. Ricerche sulla concezione escatologica ed eclesiologica dell'Adversus Haeres di Ireneo di Lione (Napoli 1970); H. Von Campenhausen, Kirchliches Amt und geistliche Vollmacht in den ersten drei Jahrhunderten (Tübingen 1963).

4 Entre varios pueden verse: J. Ochagavía, Visibile Patris Filius. A Study of Irenaus' Teaching on Revelation and Tradition (Roma 1964), 174-205; H. HolsteIn, "La tradition des Apôtres chez saint Irénée» en Recherches de Science Religieuse 36 (1949), 229-270; ID., "Les témoins de la révélation d' après Saint Irénée» en Recherches de Science Religieuse 41 (1953), 410-420; M. Jourjon, «La tradition apostolique chez saint Irénée» en L’Année Canonique 23 (1979), 193-202; E. Lanne «L' Église 
ticular no hemos hallado muchas investigaciones. El tema se encuentra tocado en estudios que tienen otro enfoque general, su objetivo es otro, o su extensión es limitada ${ }^{5}$. Se observa así la ausencia de un trabajo consagrado expresamente a esa temática. De tal manera que el objetivo de nuestro trabajo será el hacer una aproximación a la relación Iglesia-Espíritu Santo en la obra de San Ireneo. Intentaremos responder a la pregunta por el contenido teológico de la relación eclesiológico-pneumática y sus consecuencias: ¿Qué significa para el lugdunense pensar una Iglesia actuada por el Espíritu Santo?

Prestamos mayor atención a las ideas que expresan la relación eclesiológico-pneumática y que no siempre se agotan en los vocablos "Iglesia» y «Espíritu Santo». Nuestro estudio tendrá un desarrollo que mostrará el carácter económico de la relación Iglesia-Espíritu Santo a lo largo de la historia humana. El lugdunense en su refutación de la doctrina heterodoxa enfrentará a los llamados «espirituales» que llevan en sí mismos la «semilla de salvación» y han sido engendrados por "Sofía» (=Espíritu Santo personal $)^{6}$. Y por otra parte luchará contra la noción de una Tradición apostólica secreta ${ }^{7}$. Por estas razones aparece una problemática concreta a la cual el santo obispo dará una respuesta: la Iglesia de los

de Rome. "A gloriosissimis duobos apostolis Petrus et Paulo Romae fundatae et constitutae ecclesiae" (Adv. Haer III, 3, 2)»: Irénikon 49 (1976), 275-322.

5 Un muy buen capítulo se encuentra en la obra de H. JAschKe, allí toca el tema de la Iglesia como lugar del Espíritu: Der Heilige Geist im Bekenntnis der Kirche. Eine Studie zur Pneumatologie des Irenäus von Lyon im Ausgang vom altchristlichen Glaubensbekenntnis, 265-279. También puede verse otro muy buen estudio donde en uno de sus apartados se aborda la temática de la Iglesia y el Espíritu: Y. DE ANDiA, Homo vivens. Incorruptibilité et divinisation de l'homme selon Irénée de Lyon (Paris 1987), 225-236. También tratado por R. Polanco al estudiar el carisma profético en la Iglesia en: El Concepto de profecía en la teología de San Ireneo (Madrid 1999), 350-385. Un excelente artículo que plantea el eje vertebrador de la eclesiología ireneana en: R. Polanco, «La Iglesia, vaso siempre joven del Espíritu de Dios (Adv. Haer. III, 24, 1) Reflexiones sobre el núcleo articulador de la eclesiología de San Ireneo de Lyon» en Teología y Vida XLVIII (2007), 189-205. Se encuentra una muy lograda síntesis sobre la concepción valentiniana de la Iglesia y la causalidad del Espíritu personal en los Apuntes de eclesiología que A. Orbe anota en: Estudios sobre la Teologia Cristiana Primitiva (Madrid 1994), 167-185.

6 Cf. Adversus Haereses I, 4, 5. En adelante citaré directamente la obra principal de Ireneo. Ver también A. Orbe, Estudios..., 23.

7 Cf. A. Orbe, «Ideas sobre la Tradición en la lucha antignóstica» Augustinianum 12 (1972), 19-35. 
espirituales (escogidos) y la Tradición esotérica. En definitiva se halla frente a la relación Iglesia-Espíritu Santo ${ }^{8}$.

\section{La Iglesia se prepara para recibir el Estíritu}

La economía manifestada en el Antiguo Testamento revela la prefiguración y realización in nuce de la Iglesia en la tierra por la comunión del Espíritu con la humanidad. Esa relación se percibe a través de los gestos de los patriarcas y profetas que van mostrando al género humano preparado para ser depositario del Espíritu Santo. La íntima unión del linaje humano con el Espíritu engendra la vida de los hijos de Dios en un profundo proceso de vivificación. El Espíritu se derrama sobre todas las razas, más allá de Israel, y establece con ellos una relación de tipo esponsal. Por otra parte, existe una clara continuidad eclesial entre el Antiguo y el Nuevo Testamento. Esa realidad es vista a partir de la misión profética operada por el Espíritu Santo.

\subsection{El género humano preparado para ser depositario del Espíritu Santo}

Para Ireneo la finalidad divina de la plasmación del hombre es la de colocar en él sus dones (cf. IV, 14, 1). Ellos son expresión de la gratuidad

8 En la relación Iglesia-Espíritu Santo de la doctrina gnóstica se puede percibir: 1) Una relación de maternidad sustancial entre el Espíritu Santo y la Iglesia. Donde hay una preeminencia del matiz pneumatológico pero siempre de manera pasiva e ideal que se hace presente en las distintas realidades: pléroma, sustancia y hombres pneumáticos, germen espiritual o semilla (gnosis), Iglesia de los espirituales. 2) Cierto subordinacionismo: primacía del Padre (Dios Ignoto), luego el Unigénito (Logos Salvador, principio masculino) y por último el Espíritu Santo (Sabiduría, que es el primer salvado y principio femenino). Esta tendencia subordinacionista se manifiesta después en las distintas naturalezas de hombres, y por lo tanto en la diversa calidad de Iglesias (una espiritual y la otra psíquica). 3) Cierto determinismo: la posibilidad de salvación depende de la sustancia, de la «semilla espiritual» que se posee o no, con lo cual solo la Iglesia de los espirituales puede alcanzar la redención. Se establece un proceso histórico inconsciente, intramental por el cual se despierta al conocimiento salvador, ya poseído por comunión sustancial. De esta manera se descalifica la tarea de la Iglesia en el mundo como mediadora y se niega la oferta universal de salvación. 4) Menosprecio de lo material: todas las realidades materiales provienen de la pasión, por lo tanto están asociadas al mal. La dimensión corporal (carne) no es tenida en cuenta como posibilidad de ser cualificada. Por lo tanto lo humano es asumido solo en parte (la dimensión espiritual-cognoscitiva) y todo aquello que implica cierta visibilización externa y pública es negado. La Iglesia en su aspecto estructural e institucional no es tenida en cuenta. 
de la donación. Al usar colloco necesariamente se piensa en un recipiente que pueda contener. Para que así el linaje humano sea capaz de recibir en sí mismo a Dios mismo y su obra bondadosa. Así, de esa manera se fuera acostumbrando el género humano a ser depositario del Espíritu y participar de la comunión con Él. Esta intencionalidad de colocar su beneficencia en los seres humanos era comenzar un proceso que ayudaría a descubrir que ellos podían portar al Espíritu, y que paulatinamente lo irían haciendo (cf. IV, 14, 2).

En esta finalidad, la de acostumbrarse a portar a Dios por parte del hombre, hay una consecuencia aneja como resultado de lo que esto es capaz de provocar: la comunión con Dios. Por lo tanto esta portación no sería simplemente un acto extrínseco, como quien lleva algo adosado a sí, sino bien íntimo, como el concepto de comunión supone en el pensamiento ireneano?. Los siguientes casos permiten acercarnos a esa concepción:

9 Las imágenes de contacto entre realidades distintas son muy queridas para Ireneo: portar, comunión, unión, injerto, absorción, abrazo. Entre ellas existe una clara relación que manifiesta un vínculo entre estas distintas imágenes que también indican cierta caracterización y progreso. Veamos por ejemplo: a) Comunión (communio): comunión, asociación, sociedad, comunidad, comunicación, participación mutua: Spiritus Dei habitat in vobis, hoc autem non secundum jacturam carnis sed secundum communionem Spiritus fit... (V, 8, 1); et esse eum qui sit talis non jam carnales, sed spiritalem, propter Spiritus communionem (V, 9, 2); ...propter Spiritus communionem... (V, 11, 1). b) Tomar esposo (assumo): tomar a su cargo para sí, añadir a lo que se tiene o posee, usado en el Derecho Romano, el varón poseía a la mujer: Sicut igitur sponsa assumere sponsum non potest, asumi autem a sponso potes $(\mathrm{V}, 9,4)$. c) Rodear por dentro y por fuera (circumdo): Spiritus autem circumdans intus et foris hominen... (V, 12, 2). Este fue el vocablo latino que tradujo el griego $\pi \varepsilon \rho \iota \lambda \alpha \beta$ óv, que significa rodear con los brazos, cercar. Así aparece en la cita del Fragmento griego que se conserva. Orbe observa que este término no ha sido usado en el Nuevo Testamento ni en los Padres Apostólicos, y que en el Antiguo Testamento en Cant. 2, 6 sugiere el abrazo carnal, y en Sir. 30, 20 este abrazo aparece como ilícito (cf. A. Orbe, Teología de San Ireneo. Comentario del Libro V del «Adversus Haereses» I (Madrid 1985-1988), 551. d) Abrazar (complector): envolver, cercar, rodear, enlazar, apoderarse, abrazar, estrechar con los brazos: ...pignus complectens hominem in semetipsum... $(\mathrm{V}, 8,1)$; ...Spiritus complectitur carnem... (V, 13, 4). e) Deleitar (delecto): atraer, retener, deleitar, producir placer, agradar, complacer, seducir: ... mundum templum esse vult, ut delectetur Spiritus Dei in eo, quemadmodum sponsus ad sponsam (V, 9, 4). Estas expresiones en su mayoría parecen expresar el amor de los esposos. De allí que la noción de comunión ireneana tiene que ver con un abrazo que el Espíritu, una de las manos de Dios, hace a la carne y que por lo tanto posee un marcado carácter esponsal. La comunión como don comienza como una preparación en el Antiguo Testamento, después se da como arras, en el Nuevo Testamento, donde 
a) La comunión del Espíritu y la maternidad de las dos sinagogas: Lot (cf. IV, 31, 2). El agente que fecunda dando y garantizando la igualdad en la filiación y por lo tanto la unidad entre las dos realidades testamentarias es el Espíritu de Dios (semen vitale-Patris). Este es donado en el momento en que se acuesta y duerme Lot con sus hijas ${ }^{10}$ (cf. Gn 19, 33ss.). Ese mismo gesto es leído implícitamente aquí por Ireneo desde el acontecimiento pascual deducido por las indicaciones que da en el texto acerca del Hijo del Hombre.

b) El Espíritu habita en el tabernáculo (cf. Epid. 26). La figura del tabernáculo, plásticamente expresa la realidad de un recipiente que contiene la manifestación del Espíritu de Dios pero que es expresión visible y terrenal de esa realidad invisible y espiritual. El mismo Ireneo se la aplica a la Iglesia como figura que es capaz de poner en contacto a Dios con su

este abrazo no es del todo completo porque es pignus (cf. V, 8, 1)y se consumará al final cuando lo «rodee por dentro y por fuera» (cf. IV, 39, 2). Aquí parece estar presente la imagen del Arca de la Alianza (cf. Ex 25, 11) que estaba adornada con oro por dentro y por fuera, y en esta imagen hay una prefiguración de lo que será el hombre totalmente transfigurado. Mientras tanto la posesión del Espíritu va haciendo que el individuo vaya tomando las características del que está unido a él, en una especie de comunión de vida íntima. El Papiro Iena 9, 33 trae $\kappa o r<v \omega v i ́ \alpha v . .>$, que el traductor latino pone por communio (cf. V, 9, 2). En lengua griega tiene más fuerza el matiz nupcial, de tener en común, de relaciones íntimas; también el de asociación, poner en comunidad, etc. Allí el Espíritu se «deleitará» en la pureza interior del templo, o sea el hombre. Explícitamente se dice que es el modo como el «esposo toma a la esposa», entonces la carne es la esposa y es tomada en matrimonio por el esposo, el Espíritu, y a él pertenece y no al revés. Las categorías nupciales ayudan a comprender e imaginar mejor la obra del Espíritu en la carne, inteligiendo así el concepto de comunión.

10 Este hecho que puede parecer inmoral necesita ser interpretado porque esconde un misterio más profundo, por eso Ireneo hace esta aclaración: "Al ignorar, por consiguiente, el hombre y no servir a la libido, llevábase a cabo la dispensación, según la cual las dos hijas, esto es las dos sinagogas, eran adoptadas fuera de carnal libido por un solo y mismo Padre» (IV, 31, 1). Dos elementos se remarcan, por una parte la exclusión de la libido como expresión de un apetito meramente carnal, y por otro lado habla del cumplimiento de la dispensación, o sea, estaba entrando el misterio de la salvación en ese acontecimiento, y así se califica este acto de una manera más eminente. Es interesante destacar, a partir de aquí, un claro principio exegético del lugdunense donde el valor de la letra se subordina a su prefiguración: «De aquello que las Escrituras no reprenden, y simplemente consignan, no debemos hacernos acusadores; pues no somos más celosos que Dios, ni podemos superar al Maestro. Tócanos inquirir su valor de figura (sed typum quaerere), porque nada de cuanto consignan sin acusación las escrituras está de sobra» (IV, 31, 1). 
pueblo. Ella es hecha para custodiar. O sea, manifestando la conciencia de un claro tesoro que se posee y que además adelanta una realidad futura. El tabernáculo o arca era la portadora de esa realidad que simbolizaba la manifestación del dedo de Dios, su Espíritu en la Ley. Una dimensión externa pero interna a la vez se conjuga en este pasaje.

c) El Espíritu se derrama en toda la tierra: Gedeón y el vellón ${ }^{11}$ (cf. III, 17, 3). La privación del Espíritu para Israel es el otro lado del comunicado al mundo entero, la ayuda prometida ya no va dirigida a Israel, al vellón empapado de rocío, sino a la humanidad en general ${ }^{12}$. Eso fue un don previsto (muneris gratiam praevidens) por Gedeón. El uso de esa categoría enfatiza el hecho de la gratuidad. Ireneo en III, 17, 2 había identificado este regalo (munus) como el «Espiritu Santo enviado a toda la tierra». Es el mismo Espíritu que descendió sobre el pueblo de Israel, sobre el Señor Jesús, sobre la Iglesia y toda la tierra.

d) Esponsales de Dios con el género humano: Oseas y su matrimonio con la ramera ${ }^{13}$ (cf. IV, 20, 12). Este matrimonio es un signo que prefigura y va mostrando de antemano los esponsales de Dios con el género humano, considerado como «tierra» en la exégesis que hace del pasaje del profeta, y construyendo con ellos la Iglesia. Ellos quedan santificados por la unión con el Hijo estableciéndose un paralelismo con la mujer que es santificada por su unión con el profeta.

e) Las nupcias con la Iglesia de los paganos: Moisés toma como mujer a una etíope ${ }^{14}$ (cf. IV, 20, 12). Esta figura asociada al injerto del olivo malo en el olivo bueno que se enriquece por la savia que brota del bueno representa al Espíritu Santo ${ }^{15}$ que recibe al injertado y es capaz de elevarlo, de convertirlo en lo que es su esposo. Vemos aquí una transformación de una mujer (Iglesia) por el contacto con el otro (matrimonio) que es la comunión con el Verbo ${ }^{16}$.

11 Cf. Jue 6, 36-40.

12 Cf. H. Jaschke, Der Heilige Geist im Bekenntnis der Kirche..., 272.

13 Cf. Os 1, 2.

14 Cf Ex 2, 21.

15 Ireneo trabaja in extenso la analogía del olivo salvaje-olivo fértil en V, 10, 1-2. Allí se insiste en la acción del Espíritu en la carne que hace del hombre un ser espiritual que se manifiesta en sus obras. Cf. A. Orbe, Teología de San Ireneo. Traducción y comentario del Libro IV del «Adversus Haereses» (Madrid 1996), 316 nota 100.

16 Cf. R. Polanco, El concepto de profecía..., 80-81. 
f) La salvación de la Iglesia pecadora y gentil (cf. IV, 20, 12): el caso de Rahab $^{17}$ la prostituta pagana que recibe en su casa a los tres espías (las tres personas de la Trinidad). Aquí la Iglesia que viene de los gentiles y culpable por sus pecados (meretriz y pagana) pasa a ser Iglesia de Jesús $^{18}$, al recibir a los espías ${ }^{19}$. Este recibir (suscipio) se traduce en una confesión de fe en las tres Personas que la visitan, supone un acoger profundo por parte de la meretriz pagana. Nuevamente aparece una imagen continente: la casa de la familia (universa domo) que recibe, acoge y esconde (abscondo) hacia adentro, al Padre, al Hijo y al Espíritu Santo.

g) Todos reciben el Espíritu de vivificación: Jacob y los hijos de las dos hermanas (cf. IV, 21, 3). La acción del Espíritu encierra con fuerza las descripciones de los actos proféticos precedentes. Se subraya que por ella Cristo se une a toda la humanidad, en claro sentido universal, vivificando: transmitiendo vida divina e incorruptible.

\subsection{La misión de los profetas operada por el Espíritu}

Los profetas son el lagar del Espíritu preparado por Dios dentro de la viña que es el género humano: "...y cavó un lagar (torcular), preparando asi un receptáculo (receptaculum) del Espiritu profético» (IV, 36, 2). Se

\section{Cf. Jos 2, 1 ss.}

18 Ireneo, al introducir la cita de Mt 21, 31, hablando de la precedencia de los publicanos y prostitutas en el Reino de los cielos, está dando una característica de la conformación de la Iglesia querida por Jesús y leída desde este acontecimiento veterotestamentario.

19 El texto bíblico narra la existencia de dos espías (cf. Jos 2, 1. 4). Pero Ireneo añade una tercera persona, aclarando que representan al Padre, al Hijo y al Espíritu Santo. Esta introducción tiene una clara finalidad teológica impuesta por la lex orandi de la Iglesia primitiva: integrar la fe trinitaria en la formación de la comunidad eclesial. Pero el texto dice: «Patrem scilicet et Filium cum Spiritu sancto». La partícula cum puede ser el testigo de que algo está siendo introducido distinto del relato original. Es cierto que también podría leerse una pequeña "vacilación» en la integración de un esquema binario con un ternario en la teología ireneana de Dios. Cf. R. Polanco, El concepto de profecía..., 82. Según Orbe, la adición del tercer espía viene dada a la luz de Epid. 27, donde junto a los doce exploradores de la tierra prometida (cf. Núm 13, 2-14, 38) se suma como guía invisible «el Poder del nombre de Jesús». En el texto que estamos estudiando a los dos espías visibles (Padre-Hijo) se suma uno invisible (Espíritu Santo), de ahí el cum. Cf. A. Orbe, Parábolas evangélicas en San Ireneo II (Madrid 1972), 100 nota 54. 
repite la figura continente para expresar el modo de recibir la acción del Espíritu. Los profetas son prototipo de la comunión con Él: portando al Espíritu aquí en la tierra mostraban así la grandeza del dador de los bienes y la indigencia humana para receptar los dones de Dios ${ }^{20}$. La operación del Espíritu se descubre al percibir la misión de los profetas (cf. Epid. 6. 42). Ellos transmiten un mensaje que es motivado por el Espíritu Santo ${ }^{21}$.

Hay una realidad eclesial presente en el Antiguo Testamento operada por el Espíritu de Dios. Él se manifiesta actuando en la época de los patriarcas y profetas preformando allí mismo a la Iglesia. Las realidades que allí suceden no son meramente simbólicas, sino que son acontecimientos que van realizando y anticipando verdaderamente el hecho eclesial. Este proceso adquiere sentido integral dentro de la perspectiva de las disposiciones en la economía salvífica. La humanidad es el receptáculo del don de Dios y experimenta la comunión con Él convirtiéndose en portadora del Espíritu Santo como el tabernáculo de la alianza. La relación Iglesia-Espíritu Santo en el Antiguo Testamento es un anticipo real de lo que será la plenitud de la donación del Espíritu en el Nuevo Testamento.

\section{La Iglesia hechura de las manos de Dios en el mundo}

\subsection{La Iglesia vaso del Espíritu}

Hay una imagen que resulta clave en la comprensión de la eclesiología

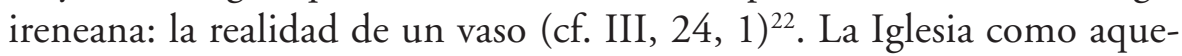

20 En IV, 14, 2 el obispo de Lyon había expuesto que los profetas habían sido preparados para llevar (portare) al Espíritu y que en ellos se adelantaba lo que sería la consumación final de los elegidos.

21 A través de ellos se proclaman las economías (cf. I, 10, 1) que manifestarán el misterio de Jesucristo, la recapitulación de todas las cosas en Cristo y la resurrección del género humano. Son heraldos de la revelación de Nuestro Señor Jesucristo. El Espíritu les muestra al Hijo. Y al anunciar al Hijo, puesto que este lleva al Espíritu consigo, hay una acción conjunta donde el Verbo une consigo al Espíritu en la acción profética (cf. Epid. 5). Su mensaje se convierte en una enseñanza destinada a aconsejar al pueblo y convertirlo al Dios de sus Padres (cf. Epid. 30).

22 Se trata de un texto con una construcción difícil que permite varias interpretaciones. Algunos autores se inclinan por identificar eximium depositum=fe (como objeto) (cf. F. Sagnard, Irénée de Lyon. Contre les Hérésies. Mise en lumière et réfutation de la 
lla que posee y contiene en su interior una bebida valiosa y plena de frescura. El Espíritu Santo es el que a su vez hace que este recipiente se mantenga siempre rejuvenecido. Esta afirmación nos ayuda a comprender la relación Iglesia-Espíritu Santo en el Nuevo Testamento. La Iglesia como realidad continente actuada por el Espíritu es un don del Padre en Cristo que se encuentra profundamente entroncada en el misterio trinitario. La Iglesia es verdadera receptora de este regalo divino. En el pensamiento ireneano hay un paralelo entre la formación del cuerpo del hombre y la constitución de la Iglesia: una eclesiología inseparable de la antropología y una antropología que desemboca en una eclesiología ${ }^{23}$.

Observamos los siguientes aspectos que constituyen la donación. En primer lugar hay una forma particular en que se ha dado: al modo del soplo primigenio que anima a la criatura humana (aspiratio-plasmatio)

prétendue «connaissance». Livre III (SC 34) (Paris 1952), 399-401; A. RousseAu, L. Doutrelau, L., Irénée de Lyon. Contre les Hérésies. Livre III (SC 211), 2 vol (Paris 1974), 389; N. Brox, Irenäus von Lyon Adversus Haereses. Gegen die Häresien III [Freiburg 1995], 297. Otros estudios señalan la presencia del Espíritu Santo como el agente vitalizador de la fe y la Iglesia como lugar del Espíritu (cf. H. Jaschke, Der Heilige Geist im Bekenntnis der Kirche. Eine Studie zur Pneumatologie des Irenäus von Lyon im Ausgang von altchristlichen Glaubensbekenntnis (Münster 1976), 267.278; A. Orbe, Teología de San Ireneo I..., 583; ID, Teología de San Ireneo II..., 314; ID, Teología de San Ireneo III..., 571; Y. De Andia, Homo vivens..., 225-236; R. Polanco, El concepto de profecía..., 240, nota 200; R. Polanco, La Iglesia, vaso siempre joven del Espíritu de Dios ..., 192-194; G. BARDY, La Théologie de l'Église..., 195). Nosotros optamos por la segunda interpretación: el Espíritu de Dios, don precioso que rejuvenece a la fe y a la Iglesia. Pensamos que la frase hoc enim Ecclesiae creditum est Dei munus, explicita el sentido de la oración que estamos analizando. Elegimos una concepción dinámica que considera la actividad del Espíritu frente a la primera idea más estática (solo receptiva). Además, el lugdunense usa la imagen del vino para expresar la identidad de la bebida (=Espíritu Santo) que contiene el vaso: vinun=Spiritus (cf. A. Orbe Parábolas I..., 253-254). En IV, 33, 14, el santo de Lyon habla del cumplimiento de la promesa del derramamiento del Espíritu como el «vino nuevo en odres nuevos» (cf. Mt 9, 17). Ireneo en III, 4, 1 dice: quasi in depositorium dives plenissime in eam contulerint omnia quae sint veriatis...: "L'image du cellier, qui indique un cellier de vin, ne pourrait-elle être mise en relation avec le vin de Cana (cf. III,16, 7) (...) même Dieu octroie aussi au genre humain, dans les derniers temps, par l'entremise de son fils,la bénédiction de la Nourriture et la grâce du Brevage (gratiam potus)» (Y. De Andia, Homo vivens..., 232, nota 36). En la Iglesia se cumple la promesa del Antiguo Testamento y ella es el "odre nuevo" (receptáculo siempre joven) por el Espíritu que ha sido efundido en su interior.

23 Cf. Y. De Andia, Homo vivens..., 225-226. 
dándole vida. Principio vital aunque imperfecto en los orígenes, pero que sin embargo es vehículo del Espíritu ${ }^{24}$. Luego se cualifica y alcanza su perfección por la comunión con Cristo (comunicatio Christi). Ya que Él fue ungido con el don del Espíritu en plenitud (cf. III, 17, 1) y por eso lo puede participar, comunicándoselo a los miembros (omnia membra) de su cuerpo. Esto ocurre en Pentecostés y la Iglesia queda así constituida como Cuerpo de Cristo. Este hecho puede interpretarse como una especie de nueva creación ${ }^{25}$. En segundo lugar hay implícita una dinámica que sostiene este proceso de vivificación: que va desde la creación a la consumación. Esta fuerza, que permite un progreso hacia la perfección en cada una de las partes y a la vez en el todo, es operada por la participación del Espíritu Santo. Las siguientes imágenes permiten descubrir un claro camino en este sentido y donde cada una supone la anterior. Cada una de ellas agrega un grado de profundización mayor hasta poder alcanzar a Dios definitivamente:

a) Arras de incorruptibilidad ${ }^{26}$ : la recepción de una parte, a partir de la efusión del Espíritu en el bautismo y resurrección de Cristo, como anticipo de la presencia total de Dios en la incorrupción final. Cada uno recibe esta señal de garantía a través de la adopción filial. Ya es una realidad divina presente aunque incompleta.

b) Confirmación de la fe: se realiza una consolidación de la salvación a través de la apropiación vital de lo que esta «prenda» suscita. Es un progreso hecho por la fe hacia lo mejor manifestado en los frutos del Espíritu (cf. V, 10, 1-2). Cada uno de los sujetos se entrega a la economía de Dios mediante un acto libre y personal de adhesión a la predicación de la Iglesia ${ }^{27}$. El Espíritu persevera en el hombre y nunca lo abandona evitando así la corrupción que pueda venir prin-

24 Cf. V, 12, 2. Ireneo diferencia el soplo vital (afflatus) dado a todos los pueblos de la tierra, del Espíritu vivificante (Spiritus vivificans) derramado en Cristo y sobre el género humano en los últimos tiempos. El primero es concedido a Adán como vida (divina) aunque de modo imperfecto mientras que a Cristo se le comunica en plenitud. Cf. A. Orbe, Teología de San Ireneo I..., 534-537.

25 Cf. R. Polanco, La Iglesia, vaso siempre joven del Espiritu de Dios..., 193

26 Cf. V, 8, 1. En este pasaje aparece «arras» (pignus) o prenda, como una partecilla del Espíritu que dispone y prepara para la incorrupción, es una presencia íntima, comunional, que inhabita en la carne, no la anula sino que lo «mortal es absorbido por lo inmortal».

27 Cf. I, 10,1. Aquí aparece el objeto de la fe trinitaria trasmitida por la Iglesia. 
cipalmente por doctrinas extrañas y heterodoxas que conducen a la muerte $^{28}$.

c) Escalera de ascenso a Dios ${ }^{29}$ : esta metáfora indica que el camino hacia las alturas es una forma de alcanzar la vida de Dios, en una comunión plena con Él. Esta expresión grafica una imagen de progreso en el proceso de divinización-visión. Se destaca así que la Iglesia desde su esencia más profunda, es gracia, siendo instrumento del Espíritu que en ella está y que ella dona ${ }^{30}$. De esta manera permite un crecimiento y desarrollo hacia la perfección de la posesión de Dios. Por esa razón hay un estrecho vínculo entre la Iglesia y el Espíritu (Ubi enim Ecclesia, ibi et Spiritus Dei; et ubi Spiritus Dei, illic Ecclesia).

En ella (in ecclesia) han sido puestos los apóstoles, profetas, doctores. Estos ministerios son una de las manifestaciones de los carismas del Espíritu $^{31}$. Por lo tanto esta relación permite afirmar que la Iglesia es el lugar del Espíritu. Pero este concepto no debe entenderse como una localización espacio-temporal. Debe comprendérsele en el orden espiritual: como el ámbito propio de las operaciones del Espíritu de Dios (universa operatio Spiritus) ${ }^{32}$. Además, el santo dice que en esta relación íntima establecida entre Espíritu-Iglesia está toda gracia (omnis gratia) porque la verdad es la manifestación del Espíritu (Spiritus autem Veritas). De esta afirmación se sigue por lo tanto que en la Iglesia se custodia el carisma de la verdad. La presencia del Espíritu de Dios convierte a la

28 Cf. V,12,2. "Quien rodea desde fuera evita la dispersión venida - ab extrinseco-; mas no la corrupción que proviene desde dentro». (El afflatus: solo desde afuera, en cambio el Spiritus: por dentro y por fuera). Cf. A. Orbe, Teología de San Ireneo I..., 551 .

29 En V,5,1 se pone como una acción de las manos de Dios la de «llevar al plasma a cuestas para ir a lo alto». En Epid. 5 y 7 aparece el «elevar» como una acción conjunta del Hijo y del Espíritu. En III, 11, 8 usa la imagen de «las alas para elevarse al reino de los cielos». Y en V, 12, 2 al hablar de una acción que «al erigirse hacia lo mejor» por la asunción del Espíritu muestra una manera de alcanzar la vida en contraposición a quien «declinando a lo peor perdió la vida».

Cf. H. Jaschke,, Der Heilige Geist im Bekenntnis der Kirche..., 267.

Cf. IV, 26, 5. Aquí Ireneo relaciona la posesión de esos carismas con el modo de asegurar el aprendizaje de la verdad en la Iglesia. R. Polanco, La Iglesia, vaso siempre joven del Espiritu de Dios ..., 201-202.

32 Cf. R. Polanco, La Iglesia, vaso siempre joven del Espiritu de Dios ..., 192-194. 
Iglesia en un receptáculo divino (cf. III, 4, 1) en el que desde siempre está contenida la verdad como una bebida vital ${ }^{33}$.

La formulación de la ecuación: Iglesia-Espíritu-verdad se da porque el Espíritu es la verdad y su presencia convierte a la Iglesia en el hogar de aquella ${ }^{34}$. Es fundamental este texto del obispo de Lyon en su refutación frente a aquellos que «... beben agua corrompida por el lodo y no quieren ser convencidos de su error rechazando al Espiritu para no ser instruidos" (III, 24, 1). La verdad guardada en la Iglesia no es una determinación arbitraria, una mera construcción del intelecto humano, sino la señal de lo que ella da como testimonio: el Espíritu de Dios ${ }^{35}$.

El ubi enim ecclesia en el pensamiento del lugdunense muestra que la Iglesia se encuentra en todo el mundo: "...porque por todas partes (ubique) hay quienes reciben el Espiritu» (IV, 36, 2). En todo el orbe florece la Iglesia, porque el Espíritu no conoce barreras. El Espíritu Santo no está dispersado difusamente por la tierra sino que se da a conocer en la constitución histórica de la Iglesia ${ }^{36}$. Por esta razón no puede dejar de ser considerado también el mundo como lugar donde se juega la relación Espíritu-Iglesia. Sin embargo, esta apertura universal siempre está circunscripta por un elemento determinante: la participación de los hombres en el Espíritu. Es un proceso de nutrición que la madre (Iglesia) otorga a todos los que beben de la fuente purísima del Cuerpo de Cristo. Aquellos (herejes) «que huyen de la fe de la Iglesia» no participan de la vida que se les ofrece a través de la mediación eclesial. Ireneo contrapone allí la imagen de los pozos que no pueden contener nada porque sus paredes están agrietadas; están viejos perdiendo toda capacidad continente.

El santo obispo define a la Iglesia como el cuerpo de Cristo (cf. IV, $33,7)$ y establece una conexión entre el cuerpo de Cristo y la eucaristía (cf. V, 2, 3). Los cristianos se transforman en cuerpo de Cristo mediante la eucaristía. El cuerpo del Señor toma forma en la Iglesia porque el cuerpo y la sangre de Cristo están presentes en la eucaristía ${ }^{37}$. El cuerpo

\footnotetext{
33 Cf. Apoc 22,17.

34 Cf. H. Jaschкe, Der Heilige Geist im Bekenntnis der Kirche..., 278.

35 Cf. H. Jaschкe, Der Heilige Geist im Bekenntnis der Kirche..., 267.

36 Cf. H. Jaschke, Der Heilige Geist im Bekenntnis der Kirche..., 266.

37 Cf. H. Jaschke,, Der Heilige Geist im Bekenntnis der Kirche..., 268-271.
} 
del Señor glorificado es el instrumento por el cual se dona el Espíritu Santo. En la cruz entrega su Espíritu (Jn 19, 30) y de su costado brota sangre y agua (Jn 19, 34). La Iglesia se muestra así como el cuerpo visible de Cristo donde los creyentes pueden saciar su sed y ser alimentados por el Espíritu ${ }^{38}$.

\subsection{Relaciones Trinitarias en la Iglesia}

La relación Iglesia-Espíritu Santo, se entiende a partir del vínculo entre la Trinidad, los seres humanos y el resto de las criaturas del mundo:

a) Iniciativa divina: las manos de Dios (cf. IV, 20, 1). La Iglesia es hechura de las "manos divinas» ${ }^{39}$ porque ella está asentada en el mundo y formada por hombres que fueron constituidos, creados y adornados por Dios. Los tres verbos que se utilizan aquí son una referencia a las personas divinas: Padre=constituo; Hijo=facio; Espíritu Santo $=a_{d o r n o} o^{40}$. Se establece así una relación de contacto entre la Trinidad y las criaturas, entre lo espiritual y lo material. Las «manos» han dejado sus huellas en la obra creada. Las tres personas divinas actúan en conjunto pero cada una con su índole personal: el Padre como autor principal, el Hijo como paradigma del hombre y el Espíritu Santo como complemento dinámico ${ }^{41}$. Esta acción es sin intermediarios: ni ángeles, ni ningún otro tipo de potencia. Se caracteriza por ser libre y espontánea. De esta manera se destaca el protagonismo del amor y la plena conciencia de Dios en su obra.

b) Eficacia trinitaria (cf. V, 18, 2). Porto sugiere una realidad de contacto: el Padre sostiene a toda la creación y al Verbo. El Hijo es sostenido en cuanto crucificado y esto es posible porque se ha encarnado. La efusión del Espíritu al mundo y a la Iglesia se da desde el Verbo crucificado y sustentado en su humanidad por la encarnación (cf. III, 17, 1). La comunicación del Spiritus que el Verbo realiza por voluntad

38 Cf. R. Polanco, La Iglesia, vaso siempre joven del Espiritu de Dios..., 193.

39 Las «manos de Dios» es una expresión típica y muy querida en el vocabulario del Obispo de Lyon para hacer referencia al Hijo y al Espíritu Santo (Verbo y Sabiduría). Cf. IV, pref, 4; 20, 1; V, 1, 3; 5, 1; 6, 1; 28, 4; Epid. 11 entre otros. Se convierten así en instrumento divino: per manus.

40 Cf. IV, 20, 2: «Dios que hizo (facio) todas las cosas por (su) Verbo y las adornó (adorno) por (su) Sabiduría (=Espíritu)». Ver también: I, 22, 1; II, 30, 9 y IV, 20, 4.

41 Cf. A. Orbe, Teología de San Ireneo IV..., 275. 
del Padre está destinada a todas sus criaturas como un don directo, pero que sin embargo, no es igual en todas ellas. En primer lugar dio el Espíritu a todo el mundo por la creación ${ }^{42}$. Este Spiritus conditionis es múltiple y se encuentra en todas las criaturas. En esto se percibe una dimensión cósmica de armonía y hermosura, como anima mundi: "... alli donde el Espiritu pone en orden y en forma la múltiple variedad de las potencias, justa y convenientemente el Verbo es denominado Hijo, y el Espiritu, Sabiduría de Dios» (Epid. 5). El Espíritu Santo actúa cohesionando y conservando vitalmente el ser de lo creado ${ }^{43}$. En segundo lugar concede el Espíritu solamente a los hombres (justos del Nuevo Testamento). Este Espíritu (ex Deo), en una nueva donación concede la filiación adoptiva ${ }^{44}$. El Spiritus adoptionis ${ }^{45}$ engendra hijos para Dios, de este modo hay una verdadera generatio: " $Y$ en todos nosotros está el Espíritu que grita: Abba, Padre» ${ }^{46}$. El Espíritu levanta la condición humana al nivel de Dios ${ }^{47}$. Ireneo cita Ef 4, 6 (por dos veces en el texto analizado) demostrando su particular interés en remarcar la eficacia trinitaria en este logion paulino: el Padre actúa super omnes, el Verbo per omnes y el Espíritu in omnibus ${ }^{48}$. Hay una eficacia natural por la cual el mundo está sostenido por el Padre a través del Verbo, por quien hace todas las cosas. Así, entonces, el Padre es Cabeza de Cristo, permitiendo que la creación sea conservada en su ser. También existe otra eficacia de tipo salvífico a través de la carne glorificada del Verbo. El Padre infunde su Espíritu de adopción sobre el género humano salvando a la Iglesia inserta en el mundo. Por esto es

42 Cf. Sab 1, 7.

43 Cf. V, 2, 3; II, 35, 3; IV, 6, 2. En estos pasajes aparece como el «Espiritu que todo lo contiene».

44 Cf. V, 12, 2. Aquí Ireneo habla de Spiritus en contraposición al afflatus: el primero es definitivo, incorruptible, eterno, en cambio el segundo es algo temporal, corruptible. En este texto se asigna con propiedad Dios al Espíritu: Spiritum quidem proprie in Deo deputans. Y la adopción de los hijos es realizada en los últimos tiempos (cf. Hch 2, 17).

45 Sobre el tema véase A. Orbe, Espiritualidad de San Ireneo (Roma 1989), 151-184.

46 Cf. III,6,1;V,6,1;8,1; Epid.5.

47 Cf. III, 6, 1. Aquí el santo introduce una cita del Sal 81,1 donde dice: «dioses son, los que son hijos del Altísimo" y los relaciona con aquellos que han experimentado la gracia de la adopción. Ver también III, 19, 1.

48 Cf. A. Orbe, Teología de San Ireneo II..., 218-220. 
que el Verbo es Cabeza de la Iglesia y se convierte así en un principio inmediato del Espíritu para ella, pero siempre como mediador entre el Padre y los creyentes ${ }^{49}$.

La unción es también otra imagen de contacto que el obispo de Lyon usa para mostrar las relaciones trinitarias: el Padre es el que unge, el Hijo el ungido y el Espíritu la unción misma ${ }^{50}$. La unción de Cristo por el Espíritu tiene un fin soteriológico: «Descendió, pues, sobre él (Cristo) el Espiritu de Dios, de aquel que por los profetas habia prometido ungirlo, para que nos salvásemos, al recibir nosotros de la abundancia de su unción" (III, 9, 3). Es una unción compartida con todos los miembros del cuerpo eclesial: «los que participan del reino, es decir, sus discípulos» (Epid. 47) que la han recibido por el bautismo. Se produce una comunicación de la salvación a los hombres a través de la persona del Verbo encarnado, ungido en cuanto hombre y que posee el Espíritu en plenitud. De allí que pueda afirmarse: la salvación como posesión del Espíritu ${ }^{51}$. Junto a esta unción mesiánica va una de carácter cósmico ${ }^{52}$ que se extiende a todo el mundo. De esta manera San Ireneo está señalando que el sentido pleno de la finalidad de la unción del universo y la de Jesús, operadas por el Espíritu, se ordenan a la salvación de la Iglesia ${ }^{53}$.

c) Inhabitación del Espíritu. El lugdunense afirma una acción inhabitante del Espíritu en los creyentes: in omnibus auten nobis Spiritus ( $V$, 18, 2). Pero antes de derramarse en ellos, el Espíritu Santo ya había descendido en la misma carne de Jesús durante su bautismo en el Jordán (cf. III, 17, 1). La carne de Cristo es el continente del Espíritu. Cristo recapitula en sí mismo a todos los hombres. La humanidad es tocada por el Espíritu divino que se acostumbra a morar (habitare) en el género humano. El uso del participio adsuescens más los tres infinitivos habitare, requiescere y habitare indican un doble sentido. En presente: el principio y comienzo de este «acostumbramiento» en Cristo. En futuro: la extensión y prolongación en el tiempo de esta presencia

\footnotetext{
49 Cf. A. Orbe, Teología de San Ireneo II..., 223.

50 Cf. A. Orbe, Teología de San Ireneo III, 6, 1; 17, 1; 18, 3; Epid. 9, 47.

51 Cf. J. González Faus, Carne de Dios. Significado salvador de la Encarnación en la teología de San Ireneo (Barcelona 1969), 59-63.

52 Cf. Epid. 9.

53 Cf. A. Orbe, La Unción del Verbo [Estudios Valentinianos III] [Roma 1961], 524.
} 
del Espíritu ${ }^{54}$. Ireneo al decir que el Espíritu se acostumbra a reposar (requiescere) en los hombres está afirmando una permanencia a través de un verbo de contacto. En un solo ser (el de Cristo), el Espíritu Santo se prepara para ser distribuido a todos los que participarán de la muerte y resurrección del Señor. Por segunda vez en el texto se afirma el habitare, pero explicitando que el lugar de la inhabitación es el hombre entero (cuerpo y alma): la plasmación (in plasmate Dei). El concepto antropológico del plasma en nuestro autor supone la idea de la criatura humana que ha sido modelada por Dios a su imagen, que perdió la semejanza y que permanece inacabada. Entonces por la acción del Espíritu que empieza a habitar en el hombre por la encarnación se produce una verdadera renovación del hombre (renovans eos a vetustate in novitatem Christi): es una nueva creación. Hay una nueva donación del Espíritu de Dios que se une a la criatura humana, morando en ella y trasmitiendo la misma vida de Cristo. De esta manera puede crecer y desarrollarse en su ser por la acción del Espíritu en el tiempo que va hasta la parusía. Así, esta novedad inaugura un tiempo nuevo: el Nuevo Testamento. El Verbo hecho carne es el principio de la vida nueva de la humanidad que como cabeza irriga sobre ella su vida incorruptible por su Espíritu Santo. El Espíritu habituándose a la humanidad de Cristo va confiriéndole la unción destinada a la Iglesia en Pentecostés. De esta manera se puede observar como una "cristología del Espíritu» se prolonga en una eclesiología ${ }^{55}$.

d) Nuevo nacimiento: el Espíritu, Aqua viva ${ }^{56}$, baña a los miembros del cuerpo de Cristo transmitiendo en ellos la misma vida divina. El baño de regeneración bautismal ${ }^{57}$ hace renacer a los hombres por la acción de las tres personas de la Trinidad. Este baño habilita a los hombres para ver a Dios y los constituye en portadores de Dios (cf. Epid.7). Esta imagen de contacto, a través del agua, permite descubrir una acción interior profunda: no solo toca externamente mojando, sino que también toca humedeciendo internamente. El Espíritu Santo actúa como ministro de esta dispensación trinitaria. Él capacita para que el

54 Cf. P. Évieux, "Théologie de l'accoutumance chez Saint Irénée» en Recherches de Science Religieuse 55 (1967), 27.

55 Cf. Y. De Andia, Homo vivens..., 206-208.

56 Cf. III, 17, 2-3; IV, 33, 14; V, 18, 2; Epid. 89.

57 Cf. I, 21, 1; III, 17, 1; V, 15, 2-3; Epid. 3. 
hombre progresivamente vaya profundizando en el conocimiento en la carne rutilante (ungida por el Espíritu) del Hijo de Dios: «... la luz del Padre irrumpe en la carne de nuestro Señor, y de esa carne sus rayos se reflejan en nosotros, para que el ser humano, rodeado por la luz del Padre, se haga incorruptible» (IV, 20, 2). Así esta visión (=comunión) puede crecer hasta alcanzar la vida eterna: «Porque la gloria de Dios es el hombre viviente; y la vida del hombre es la visión de Dios" (IV, 20, 7). Para Ireneo la visión de Dios coincide con la comunión con Dios por el Espíritu: el hombre viviente es el que participa del Espíritu de Dios (cf. V, 9, 2). La incorruptibilidad se convierte así en el don mayor y final que se aspira en este proceso. El Espíritu Santo permite el conocimiento del Hijo de Dios, el Hijo acoge y presenta a los regenerados al Padre y este concede la incorrupción en la consumación final. De esta manera, el Espíritu Divino, se convierte en principio dinamizador de la vida regalada en el bautismo y que alcanzará su plenificación en la vida eterna. El hombre puede llegar a contemplar a Dios por beneplácito del Espíritu de Dios (cf. IV, 20, 8). Para el obispo de Lyon existe una condición para que el Espíritu sea derramado $(\mathrm{V}, 18,2)$ : el hombre debe creer en Cristo, amarlo y profesar el misterio de Dios en su eficacia trinitaria sobre el mundo y la Iglesia (Ef 4, 6). Ireneo parece tener en mente Jn 7, 38-39 y seguir el orden allí manifestado: creer en Jesús-recibir agua viva (cf. IV, 33, 14). Creer con rectitud (recte credentibus) es creer según la fe de la Iglesia enseñada por los apóstoles Esta recta fe lleva consigo la rectitud en el amor y en el conocimiento de Dios fundados en ella. Los hombres en la Iglesia creen, aman y conocen a Cristo (encarnado y crucificado) y así brota dentro de ella el manantial del Espíritu.

\subsection{La Iglesia en toda la tierra}

El mundo es el escenario donde la Iglesia se ubica como portadora del Espíritu en una estrecha relación con la humanidad. La Iglesia, como hemos afirmado más arriba, se encuentra en todo el mundo porque en todas las partes de la tierra hay hombres portadores del Espíritu Santo que la hacen presente. A partir del acontecimiento de Pentecostés se produce una nueva efusión del Espíritu que cumple la promesa del profeta (cf. III, 12, 1). En lugar del término "Iglesia» como destinataria de la acción del Espíritu, Ireneo también puede referirse tanto al "género 
humano ${ }^{58}$ a la "humanidad ${ }^{59} \mathrm{o}$ "toda la tierra ${ }^{60}$. En estos casos, el sujeto receptivo de la acción divina es «toda carne».

El Padre es la fuente del derramamiento del Espíritu, él lo dona al Hijo, y Cristo lo regala a los discípulos, mostrándose así un modo de participación en esta gracia: «Habiendo recibido el Señor este don del Padre, él mismo lo donó a quienes participan de él, enviando el Espiritu Santo a toda la tierra» (III, 17, 2). Todo esto permite descubrir el descenso del Espíritu sobre la humanidad como parte de la economía (dispositio) (cf. III, 17, 4).

Según el obispo de Lyon hay un soplo vital (afflatus) ${ }^{61}$ que fue otorgado en común (communiter) a todos los pueblos de la tierra, sin distinción de razas ni individuos: la turba (los hombres de la calle) ${ }^{62}$. Hay una participación pequeña, pero cierta, per afflatum en toda la realidad creada. Luego por una nueva infusión (incremento) per Spiritum se alcanza una participación plena de lo que inicialmente fue concedido. Las dos participaciones proceden de la vida divina, por lo tanto pertenecen a la vida sobrenatural que se comunica. De esta manera es posible comprender la acción de lo sobrenatural (Dios) en lo natural (carne o realidades materiales) permitiendo el progreso en el ser. No solamente el hombre progresa sino todo el mundo tiene una capacidad de ser cualificado por el Spiritus. De allí que se perfila en el pensamiento del santo obispo la realidad de la Iglesia portadora del Espíritu de Dios en medio del mundo. El Spiritus va abrazando por dentro y por fuera al mundo y al hombre (carne-realidad material). Ese abrazo se produce en esa arca incorruptible (Iglesia), donde se da la comunión plena y vivificante con el Espíritu de Dios: produciéndose así la deificación.

La estadía del Verbo hecho carne y glorioso entre los hombres permite establecer una diferencia fundamental que permite el paso de lo antiguo a lo nuevo (cf. III, 17, 1). La posesión plena del Espíritu de Vida en el segundo Adán es lo que permite comunicarlo a los demás por la adop-

\footnotetext{
58 Cf. III, 11, 9; 17, 2; V, 12, 2.

59 Cf. Epid. 6.

60 Cf. III, 11, 8; 17, 3.

${ }^{61}$ Cf. V, 12, 2.

62 «El pueblo terreno, extendido sobre la tierra (...) no tiene aquí alcance geográfico, sino moral: el pueblo que hace vida en la tierra, sin acordarse de Dios» (A. Orbe, Teología de San Ireneo I..., 541).
} 
ción filial (adoptio fliorum) ${ }^{63}$. El regalo del Espíritu se da en la medida de la participación en Cristo. Todos los hombres unidos a Él permiten que se renueve la humanidad permitiendo así la «comunión con Cristo» (III, 24, 1) ${ }^{64}$. El Verbo extiende a sus hermanos los hombres la propia filiación. El Espíritu está destinado a ser derramado sobre todos los sujetos para que sean hijos convirtiéndolos en un pueblo nuevo. La finalidad del derramamiento del Santo Espíritu es acercar más a Dios al género humano, generando la unión y comunión con Él, y de los hombres entre sí en Dios (cf. V, 1, 1). Como fruto de la pasión redentora del Señor, en Pentecostés se derrama el Espíritu del Padre sobre la Iglesia dando inicio a una comunión cualitativa del hombre con Dios que se consumará en el juicio final. Adunitio expresa la acción de unir que se ejerce penetrando y provoca un determinado efecto: communio; con lo cual se alcanza cierta relación de parentesco con Dios. Siguiéndose de esto la posibilidad de alcanzar la incorruptibilidad divina. El paralelo antitético: hominesdeponente-Deum-per Spiritum // Deum-imponente-hominem-per Incarnationem, permite observar cómo el Espíritu es el agente dinamizador del proceso descendente de la Encarnación (en la persona del Logos) y ascendente de la deificación (en la carne del hombre) ${ }^{65}$. La metáfora de los granos de trigo seco que no pueden convertirse en una masa ni en pan sin el agua, expresa la condición aglutinante y fecundante del agua. El bautismo (lavacrum) desencadena un proceso de incorrupción que introduce en la vida del Nuevo Testamento: purificando, aglutinando y fecundando. La vida se expresa en la comunión con Dios y a través de ella fructifica, por participación, en la unidad de los pueblos que estaban distantes y que son ahora reunidos. La realidad de ser unum in Christo siendo muchos es un don conferido por el Espíritu (agua que proviene del cielo). Lo múltiple y diverso no es expresión de dispersión sino posibilidad de unidad en el Espíritu. Otorgada la comunión con Dios se dona la comunión entre todos los hombres. Así, la Iglesia es unida por la acción del Espíritu Santo.

Los miembros del pueblo experimentan un llamado común y pleno de novedad como fruto de la operación del Espíritu en ellos ${ }^{66}$. Esta

\footnotetext{
${ }^{63}$ Cf. II, 11, 1; III, 18, 7; 19, 11; IV, 11, 1; V, 18, 2.

64 Cf. H. Jaschke, Der Heilige Geist im Bekenntnis der Kirche..., 268.

65 Cf. A. Orbe, Teología de San Ireneo I..., 77-78.

66 Cf. Epid. 90.
} 
novitas tiene como finalidad la renovación vital del ser humano por la participación en los dones que trae el Señor. Entre los principales dones traídos por el Señor está el del Espíritu de adopción dado a la Iglesia. El llamado común a ser un pueblo espiritual no queda simplemente como una experiencia subjetiva sino que se manifiesta visiblemente en la institución y fundación de la Iglesia (cf. Epid. 41). La Iglesia se constituye a través de la enseñanza de los apóstoles y del bautismo que ellos administran. Estos dos actos son una expresión de la acción del Espíritu Santo que obra en los discípulos como instrumentos porque ellos han sido revestidos de su poder al haberlo recibido del Señor. La enseñanza es testimonial (discípulos-testigos) a través de aquellos que en su propia vida pudieron experimentar directamente los misterios de la vida de Jesús. Cuando los apóstoles enseñan es el Espíritu el que instruye, cuando bautizan es el Espíritu el que se distribuye. Y así, a través de ellos se comunica el Espíritu a los creyentes. Hay una cadena de transmisión del Espíritu: Jesús-apóstoles-creyentes. El Espíritu de los que han recibido las enseñanzas y el bautismo es el mismo que Jesús recibió en su unción mesiánica y derramó en Pentecostés. La Iglesia es el lugar donde se entrega el Espíritu.

Se puede apreciar una apertura universal: «a los gentiles» y «por toda la tierra", o sea, destinada a todos los hombres que vivían en el mundo. Existe un destinatario concreto que se encuentra injertado en un espacio

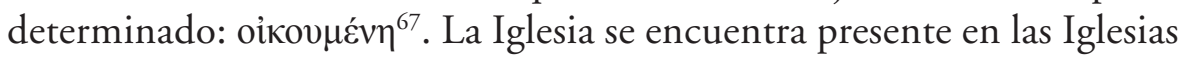
particulares diseminadas por todas partes: las de la Germania, las de Iberia, las del Oriente, las de Egipto o Libia, las constituidas en el centro del mundo ${ }^{68}$. Las distintas razas humanas son objeto de la "convocación" para participar de la alianza nueva y ser ellas mismas portadoras de este pacto en el Espíritu (cf. IV, 36, 2). A partir de la exégesis de la parábola de los viñadores asesinos ${ }^{69}$ (cf. IV, 36, 1) Ireneo quiere mostrar paradigmáticamente un paralelismo de la economía divina sobre el pueblo de Israel y la Iglesia-pueblo de los gentiles ${ }^{70}$. El nexo entre los dos se da por

67 Incluso supone un elemento geográfico, el mundo conocido: (I, 10, 1); I, 10, 2) $(\mathrm{V}, 20,1)$; o las cuatro regiones del mundo en que se habita, como expresión de la totalidad: (III, 11, 8).

68 Cf. $1,10,2$.

69 Cf. Mt 21, 33-46.

70 Cf. A. Orbe, Parábolas I..., 268. 
la forma en la que se posee al Espíritu de Dios. El lagar, depósito donde se pisa la uva, es la imagen elegida por su simbolismo: vino=Espíritu para expresar la capacidad continente que tienen los distintos sujetos para acoger al Espíritu. En el Antiguo Testamento se derrama limitadamente, solo sobre los profetas como una gracia especial, ya que ellos son algunos de los miembros del pueblo. Pero en el Nuevo Testamento lo que estaba cercado se abre a todos los creyentes haciendo de ellos hijos de Dios, receptáculos del Espíritu de adopción. De esta manera la Iglesia portadora del Espíritu se alza en medio del mundo como una "torre elegida", que ya no tiene residencia en una capital geográfica (Jerusalén). Sino que ha dilatado su llamamiento a todas las naciones (cf. Epid. 21). Los atributos «elevada» (exaltata) y "hermosa» (speciosa) se fusionan connotando una idea de vital protección, como la que inspiraba la altura (como un atalaya) y la rica actividad religiosa en torno al templo de Jerusalén. El resplandor de la Iglesia no es garantizado por una realidad externa: ni la Ley de Moisés (cumplimiento legal) o la circuncisión (pertenencia racial) simbolizados por el «cerco» (sepem circumdedit), ni el Templo de Jerusalén (identidad cultual) expresada en la "torre» (turrem aedificavit, Hierusalem elegit). Sino que, la Iglesia irradia luminosidad (praeclara), sin ningún tipo de límite ni fronteras (ubique), por la vitalidad que ella contiene, la del vino del Espíritu.

\subsection{La misión de la Iglesia en el mundo}

La actuación histórica de la Iglesia es para el santo lionés una operación del Espíritu Divino. La historia supone un elemento temporal y uno espacial: «los últimos tiempos» $\mathrm{y}$ "pueblos de toda la tierra». Este binomio entra en la relación: Espíritu-Iglesia-mundo. El Espíritu es una realidad dinámica y operante que hace que la Iglesia adquiera una forma particular al verse exigida por determinadas situaciones propias de la vida del mundo. El obispo de Lyon encuentra en las siguientes imágenes una manera de explicitar el vínculo que se establece con la presencia eclesial en medio del orbe:

a) Candelabro de siete brazos (cf. V, 20, 1). La Iglesia posee una visibilidad externa y pública que puede ser vista por todos. Se resalta así la oferta universal de salvación de la Iglesia de la cual ella es portadora ${ }^{71}$.

71 Cf. A. Orbe, Teología de San Ireneo II..., 319. 
b) Nuevo paraíso de vida: (cf. V, 20, 2). La fórmula ait Spiritus Dei es la única vez que es usada por el obispo de Lyon, lo cual hace que este pasaje guarde un sentido particular ${ }^{72}$ : es el Espíritu Santo que entabla un diálogo con los creyentes que forman parte de la comunidad eclesial, al modo como Dios hizo con Adán en el jardín del Edén. Los árboles plantados en el jardín de Adán son símbolo de lo que las Sagradas Escrituras son para la Iglesia: el paraíso. Las Escrituras solo brindan alimento y protección a toda persona que se nutre en el seno de la Iglesia. Afirmando así la importancia y necesidad de la educación eclesial para un contacto verdadero que alimente con las Escrituras. La presencia del Espíritu en la Iglesia garantiza la verdad: (cf. III, 24, 1) y es el lugar conveniente para nutrirse de las Escrituras.

c) Hospedería (cf. III, 17, 3). El santo obispo, al analizar la parábola del buen samaritano ${ }^{73}$, le atribuye al Espíritu Santo el papel de hospedero o mayordomo ${ }^{74}$; a Él se le encomienda el hombre malherido. Es tarea del Espíritu de Dios ir preparando esa resurrección final, sanando las llagas del hombre herido por el pecado. «Nada tan peculiar al Espíritu Santo, formador del cuerpo de Jesús en el seno virginal (cf. $\mathrm{V}, 1,3)$, como disponer, entre individuos llagados por el demonio y hechos salvos por el Hijo, el cuerpo del Cristo total (cf. IV, 31, 2), dinámicamente uno y multiforme» ${ }^{75}$. Si el Espíritu Santo es el hospedero, la Iglesia es la hospedería. Es la morada donde son acogidos los que por la fe han recibido la acción restauradora del Espíritu de Dios. Cada creyente bajo el influjo del Espíritu completa su curación y se dispone a fructificar para la vida eterna. Por lo tanto la Iglesia es un recinto curativo donde el Espíritu Santo restaura la humanidad herida por el pecado y la prepara para que fructifique en vida eterna.

72 En otros lugares refiere que es el Espíritu el que da testimonio a través de distintos textos bíblicos: III, 10, 4; IV, 2, 4. Ireneo comprende así el sentido pleno de la Escritura inspirada. Cf. A. ORBE, Teología de San Ireneo II..., 331.

73 En este análisis seguimos a: A. Orbe, Parábolas I..., 125-154.

74 Cf. IV, 37, 7: unus enim Spiritus Dei qui disponit omnia... «Como si tal personaje, mesonero nato de la economía humana, el que todo lo dispone como ministro del Padre, fuera el Espíritu de Dios» (A. Orbe, Parábolas I..., 125). El posadero o stabularius como símbolo del Espíritu Santo es completamente original en la historia de la exégesis. Cf. A. Orbe, Parábolas I..., 135-151.

75 A. Orbe, Parábolas I..., 128. 
d) Estatua de sal: (cf. IV, 31, 3). La Iglesia estatua de sal, es la iglesia de los mártires donde el Espíritu Santo reposa (requiesco) rejuveneciéndola permanentemente. Sufrir las persecuciones es para la Iglesia un elemento propio de su condición de estar inserta en el mundo, ya que en él se experimenta el sufrimiento humano. Estar animada por el Espíritu de Dios en esta situación lleva a la Iglesia a ponerse como un fundamento firme, conservando la fe de sus miembros. Y además, puede ofrecer a Dios un sacrificio de alianza a través de la sangre de los mártires. Es el Espíritu el que la hace crecer en la perseverancia, cuando parece disminuir. El Espíritu encauza a la Iglesia que está en medio del mundo (dimensión terrena) para que ponga su camino con dirección a Cristo (dimensión celestial).

La Iglesia como hechura de las manos de Dios es el lugar donde Dios abraza a la humanidad a través del Espíritu Santo. En la Iglesia confluye lo divino y lo humano para acercar a Dios a los hombres y los hombres a Dios en la "carne» espiritualizada del Hijo que se ha unido a toda carne humana. La Iglesia es la portadora de una alianza nueva, ofreciendo la salvación a todos los hombres. Al estar enclavada en medio de un mundo agitado, ella se constituye con firmeza por la fuerza del Espíritu que contiene en su interior.

Al pensar la relación Iglesia-Espíritu Santo nos encontramos pensando en un vínculo bien estrecho que se establece entre: Espíritu SantoIglesia-mundo. Esta relación parece ser la forma en la que Ireneo concibe a la Iglesia en el Nuevo Testamento.

\section{La Iglesia carismática}

La Iglesia como un vaso portador del Espíritu Santo, custodia en su interior el «don de Dios» que ha recibido y lo ofrece al exterior sirviendo a la humanidad. Dios puso dentro de este recipiente los ministerios (apóstoles, profetas, doctores) y el resto de las operaciones del Espíritu (III, 24, 1). Allí es «donde fueron depositados los carismas de Dios» (IV, 26, 5). Ellos son "guardados como en una rica bodega de la manera más plena» (III, 4, 1). Por lo cual se puede afirmar que la Iglesia es para Ireneo un receptáculo pródigo en carismas que manifiestan la actividad del Espíritu de Dios. El Santo Espíritu impregna de sus dones al mismo continente que lo contiene. La Iglesia (continente) se vuelve así espiritual por el Espíritu 
Santo (contenido) que le transmite las características de su misma vida divina, y así la diviniza.

Cuando la Iglesia actúa, obra de acuerdo a lo que es: manifestando externamente lo que internamente contiene. La actividad eclesial se despliega a través de sus múltiples obras reflejando su ser espiritual. La Iglesia extendida por todo el mundo tiene un objetivo bien concreto: servir a la humanidad (cf. II, 32, 4).

\subsection{El carisma de custodiar la verdad de la fe}

Los apóstoles y sus sucesores son "hombres perfectos-espirituales» porque en su ser está operante la dinámica del Espíritu de Dios (cf. III, 1, 1). Los apóstoles han sido revestidos de la virtud del Espíritu Santo quedando llenos de "todo» (sus dones) «y del perfecto conocimiento». De lo cual se colige que el Espíritu Santo les ha otorgado el conocimiento como un don. Los apóstoles, a su vez, lo han depositado en la Iglesia para que sea custodiado y para servir a los creyentes que anhelan «entrar en la vida» (cf. III, 4, 1). Por esta razón, este don es un carisma que se ordena al bien común de los cristianos: conocer para alcanzar la salud en Cristo Jesús. El conocimiento de las verdades salvíficas contenidas en la Escritura es un carisma que otorga el Espíritu Santo.

En la comunidad cristiana existen diversas manifestaciones espirituales sensibles. Estas son la expresión de una abundante acción de un mismo Espíritu. Este Espíritu fue derramado sobre la Iglesia en Pentecostés. Los hombres perfectos-espirituales han sido perfeccionados y espiritualizados por la presencia del Espíritu Santo. Según esta concepción, la perfección del ser humano se realiza en el contexto eclesial. En la Iglesia se encuentra la presencia del Espíritu Santo palpablemente manifestada en la abundancia de los carismas que adornan a los hombres perfectosespirituales. De esta manera, una vez más, se relacionan íntimamente la antropología y la eclesiología ${ }^{76}$.

Para el santo lionés los destinatarios de la enseñanza apostólica también son hombres espirituales que por la gracia del Espíritu Santo pueden acoger la verdad de la salvación: (cf. IV, 33, 7-8). Una de las cualidades propias del «discipulo realmente espiritual, en posesión (recipiens) del Espiritu de Dios (...) (es la de) juzgar (iudico) a todos sin ser él juzgado»

76 Cf. R. Polanco, La Iglesia, vaso siempre joven del Espíritu de Dios..., 197-200. 
$(\mathrm{IV}, 33,1)^{77}$. Al interpretar la cita paulina (1 Cor 2, 15) en el contexto de IV, 33, $1-7^{78}$, el lugdunense entiende «juzgar» desde dos matices: como deliberación o como condenación frente a las distintas doctrinas vigentes en su época. Esa afirmación supone introducirse en la concepción gnoseológica del santo. Según Ireneo el ser humano por su condición creatural necesita del auxilio divino para resolver todas las cuestiones planteadas en las Escrituras ${ }^{79}:$ «...el ser humano es infinitamente menor que Dios; y ha recibido la gracia solo en parte ${ }^{80}$; que no es igual o semejante a su Hacedor; y que no puede tener la experiencia o el conocimiento como Dios» (II, 25, 3). La diferencia entre la criatura y el Creador permite descubrir que se participa en el modo de conocer de Dios, aunque no idénticamente a él. A su vez esa diferenciación permite una diversidad participativa entre los miembros del cuerpo eclesial (cf. II, 28, 7). De esta consideración se sigue que el conocimiento de las verdades salvíficas contenidas en la Escritura es un carisma que otorga el Espíritu Santo. Hay que buscarlo con confianza y en actitud de abandono en las manos de Dios. Por otra parte, el Espíritu Santo otorga al "discípulo espiritual" la capacidad de conocer con consistencia, y también revela el conocimiento de la verdad (agnitio veritatis). Por lo cual, el creyente posee este don del Espíritu para asentir (assensio) a la verdad, ejercitándose en el juicio del discernimiento.

Para el obispo de Lyon, el contenido de la agnitio vera son los puntos esenciales de la fe cristiana que han sido transmitidos por la enseñanza de los apóstoles a cada una de las Iglesias diseminadas por el mundo ${ }^{81}$ que son guardados y expuestos con fidelidad: la regla de la verdad ${ }^{82}$. Por

77 Los creyentes poseen esa capacidad que obra el Santo Espíritu para aprender en la lectura de las Escrituras (AT) lo que enseña Dios con su presciencia (cf. IV,32,2). Cf. A. Orbe Teología de San Ireneo IV..., 451, nota 1-2.

78 Allí Ireneo usa iudico varias veces y en una ocasión examino (IV,33,2) frente a distintos grupos que atentan contra la verdad (gentiles, judíos, marcionitas, valentinianos y otros gnósticos, ebionitas, docetas, falsos profetas, cismáticos).

79 Cf. II,28,2. Aquí Ireneo plantea la necesidad de abandonarse a Dios para recibir su revelación y resalta el valor de las Escrituras como "perfectas» por ser inspiradas por el Verbo y el Espíritu.

80 Cf. 1Cor 13,9.12.

81 Cf. I,10,1-2;V,20,1.

82 Sobre la noción de Regla de la Verdad en Ireneo puede consultarse: A. FArvre, «Irénée premier théologien «sistemátique»?» en Recherches de Science Religieuse 55 
esta razón el espiritual «no es juzgado por ninguno» porque tiene en cuenta todos los elementos compendiados en esa regla sin omitir ni cambiar nada como hacían los grupos antes enumerados por Ireneo ${ }^{83}$. El hombre espiritual es el auténtico intérprete de la Escritura que puede descubrir el mensaje particular de cada pasaje bíblico, integrándolo al todo del mensaje del Hijo de Dios, descubriendo la acción del mismo Espíritu en los dos Testamentos (cf. IV, 33, 15).

Convergen así la gnoseología y la pneumatología en un claro contexto eclesiológico. Encontramos tres elementos íntimamente relacionados: objeto, sujeto y contexto del conocimiento. Se articulan la verdad de la fe custodiada y transmitida como objeto de conocimiento; el hombre verdaderamente espiritual (apóstoles, sucesores, los creyentes) como sujeto cognoscente y el contexto es el «rico depósito» (III, 4, 1) que es la Iglesia. El modo de la articulación está garantizado por la Tradición eclesial que supone una actitud de humildad y abandono en Dios.

\subsection{El Carisma supremo de la caridad: el martirio}

Para el santo lionés, la caridad es el principal carisma que el Espíritu suscita en la Iglesia y los mártires son los testigos de la fe y del amor vivido al extremo. El amor se convierte en motor principal del martirio junto con la confesión de fe en el Hijo de Dios (cf. IV, 33, 9). El Espíritu Santo que descendió sobre el Hijo de Dios en su Bautismo, se acostumbró a reposar en el género humano y derramándose en Pentecostés (cf. III, 17, 1-3) descansa (requiescens) sobre la Iglesia de una manera nueva (nove) porque en la carne del Hijo espiritualizó toda carne. Así los miembros del cuerpo de Cristo participan de esta nueva presencia del Espíritu que los capacita para imitar la misma actitud que el Señor tuvo frente al sufrimiento y la muerte ${ }^{84}$. El martirio se manifiesta como un carisma del Espíritu dentro de la comunidad eclesial, que en todas partes ex-

(1967), 18-24. Un excelente análisis sobre el contenido de las fórmulas de fe en Ireneo, particularmente la vinculación entre el Espíritu y la Iglesia, se encuentran en A. Meis, "La fórmula de fe "Creo en el Espíritu Santo" en el siglo II. Su formación y significado» en Anales Facultad de Teología XXIX [1978] (Santiago 1980), 180-206.

83 Cf. A. Orbe, Teología de San Ireneo IV..., 460-461.

84 Cf. III,12,13. Aquí Ireneo pone el ejemplo del diácono Esteban como aquel que imitó hasta el martirio a su maestro. 
perimenta la persecución. La dinámica debilitamiento-crecimiento que parece paradójica adquiere su sentido pleno en la medida que los que sufren el martirio no se pierden sino que son ganados para el Reino de Jesús. Esta acción de la Iglesia que «envía mártires» (praemitto) es una operación suscitada por el Espíritu que reposa sobre ella.

Esta acción había sido vaticinada por los profetas del Antiguo Testamento ${ }^{85}$. Tanto los profetas como los mártires son portadores del Espíritu de Dios. Para Ireneo los mártires son los prototipos de los hombres espirituales (cf. V, 9, 2). Los tiempos en que Ireneo desarrolla su ministerio son épocas de persecuciones y martirios por lo cual él conoce profundamente estas realidades ${ }^{86}$. El santo obispo parte su reflexión contraponiendo la frase de Jesús dirigida a la cobardía de los apóstoles en Getsemaní (cf. Mt 26, 41) a la fortaleza de los mártires que en situaciones de peligro testimoniaron con su vida la fe en Cristo. Los mártires en virtud del Espíritu que los anima, no obstante su humana debilidad, se convirtieron en testigos del Señor en el momento de la prueba. El Espíritu va elevando al hombre a la vida de Dios: la debilidad-enfermedad de la carne es vencida por la fortaleza del Espíritu. El lugdunense usa el verbo admisceo y así introduce la imagen del vino flojo corregido con la infusión de otro más fuerte ${ }^{87}$ : mostrando cómo se va realizando íntima y profundamente la comunión. La pasividad de la carne se corrige por la fuerza del "injerto-estímulo" infundido en ella. De esta manera brilla el poder del Espíritu absorbiendo la flaqueza de la carne; permitiendo así la experiencia del martirio. En definitiva los mártires aparecen como el modo acabado del ser cristiano y el argumento apodíctico contra la herejía ${ }^{88}$.

En el pensamiento de San Ireneo los carismas son la expresión rica y variada de la acción del Espíritu Santo dentro de la Iglesia. El obispo de Lyon es testigo de la vida carismática de las comunidades de su época. A su vez se halla profundamente involucrado en una controversia contra aquellos que reclaman para sí el ser verdaderos espirituales porque

85 Cf. IV,33,10.

86 Ireneo fue discípulo de Policarpo de Esmirna, mártir (cf. Eusebio, $H E$ V,20,5). También lleva a Roma la carta martirial de su Iglesia cuando aún era presbítero y luego sucede a Fotino en Lyon que ha muerto mártir (cf. Eusebio, $H E \mathrm{~V}, 4,2$ ).

87 Cf. A. Orbe, Teología de San Ireneo I..., 424.

88 Cf. E. Lanne, «L'Église de Rome... », 293. 
poseen en su interior la gnosis verdadera. También tiene que enfrentar a aquellos que bajo apariencia de signos extraordinarios e intereses personales engañan a la gente. Por eso, el santo remarca que la acción del Espíritu Santo en los carismas siempre es expresión de la gratuidad de Dios en beneficio de la humanidad. La riqueza carismática de la Iglesia, "vaso espiritual», fundamentalmente se expresa en la calidad de su custodia y transmisión de la verdad de la fe y en el testimonio de caridad suprema sellada por sus mártires.

Al considerar aquí la relación Iglesia-Espíritu Santo en San Ireneo nos encontramos en la confluencia de su antropología y gnoseología bien trabadas y plantadas en la situación histórico-existencial que le tocó vivir.

\section{La Iglesia transfigurada POR el Espíritu}

En la consideración del tiempo escatológico el obispo de Lyon lleva hasta sus consecuencias finales los presupuestos de su teología. Es necesario atender a los «tiempos del reino de los justos» ${ }^{89}$ como el marco general. Para el lugdunense «los justos» son los hombres espirituales ${ }^{90}$ que se preparan inmediatamente para alcanzar la incorruptela. Una efusión nueva del Espirítu inunda íntimamente los corazones carnales haciéndolos capaces de recibir la vida, heredando así el reino de Dios en la resurrección (cf. V, 8, 1). El omnia membra hace referencia a todos y cada uno de los miembros de la Iglesia (cuerpo) que participan de la resurrección de Cristo (cabeza) y que han sido invadidos por el Espíritu Santo ${ }^{91}$. La resurrección en el tiempo final es un acontecimiento eclesial operado por el Espíritu de Dios. El obispo de Lyon utiliza complectens ${ }^{92}$ hominen in semetipsum para expresar la idea de un abrazo iniciado pero no consumado, como el esposo atrae a sí y abraza a su esposa y se deleita en esa acción tomando

89 Cf. V, 31-36. En estos capítulos se introduce el tema del «milenio». Sobre la temática puede verse: A. Orbe, Introducción a la Teología..., 966-983; R. Polanco, «El milenarismo de Ireneo o teología antignóstica de la caro capax Dei» en Teología y Vida XLI (2000), 16-29.

90 Cf. IV,20,6,133;V,5,1,11-12.24. Aquí Ireneo habla de los justos como aquellos hombres que tienen o portan el Espíritu.

91 Cf. III, 19,3;24,1; IV,20,8;33,10.

92 El lugdunense usa complector con diversos matices. En III,15,2;V,6,2 adquiere un sesgo matrimonial. En III,16,3 y IV 20,4 el hombre es el que abraza a Dios. En $\mathrm{V}, 12,2$ es un abrazo definitivo por dentro y por fuera. En V,13,4 tiene carácter unitivo. Cf. A. Orbe, Teología de San Ireneo I..., 375.642-643. 
la iniciativa (cf. V, 9, 4). En el tiempo presente el Espíritu Santo va absorbiendo lo mortal de la carne de los hombres: la naturaleza humana (sarx) permanece, pero desaparecen las obras de la carne (cf. V, 10, 2; 11, 2). Para San Ireneo, la carne transfigurada de Cristo resucitado se convierte en paradigma de lo que le sucederá a la carne de los justos en el tiempo final con la invasión del Espíritu del Padre: «...se transfigura, porque mortal y corruptible como es, se vuelve inmortal e incorruptible» $(\mathrm{V}$, 13, 3). El Espíritu Santo, salvante y figurante (cf. V, 9, 1) tiene como tarea imprimir la figura de Dios en la realidad eclesial hasta transfigurarla totalmente en Él ${ }^{93}$. El lugdunense confirma el carácter unitivo del Espíritu con la carne a través de la imagen del abrazo: Spiritus complectitur carnem, otorgando así a los justos la capacidad de recibir la vida plena en la resurrección (cf. V, 13, 4).

La gracia universal del Espíritu. El pignus Spiritus inicial da paso a la universa Spiritus gratia. En contraposición a la pars Spiritus recibida en la filiación se recibe la universa Spiritus en la consumación como plenitud del Espíritu Santo. La «gracia universal» dada por Dios es una intensificación del don del Espíritu que otorga la perfección espiritual de la semejanza con el Padre. Los justos redivivos «...captarán en el reino la comunión (communio) y unidad (unitas) de los espirituales junto con el régimen de vida de los santos ángeles» $(\mathrm{V}, 35,1)$. Los conceptos de communio y de unitas se combinan para expresar la idea de comunión física

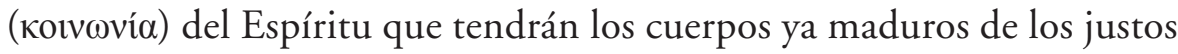
asimilándose a Dios.

Para el obispo de Lyon la dinámica eucarística permite un contacto con el Espíritu vivificante del cuerpo resucitado de Cristo y refleja análogamente en ella lo que se espera que sea obrado en los cuerpos de los justos en la consumación de los tiempos. San Ireneo establece un paralelismo entre las fases que experimentan el pan y vino eucarístico y el proceso de los cuerpos glorificados (cf. V, 2, 3). El obispo de Lyon encuadra esa actividad dentro de un contexto eclesial al indicar que el Señor alimenta (nutrio) a aquellos que son miembros de su cuerpo (cf. Ef 5,30$)^{94}$.

\footnotetext{
93 «La transfiguración ( $\mu \varepsilon \tau \alpha \sigma \chi \eta \mu \alpha \tau \imath \sigma \mu o ́ s)$ de la carne se aplica al cambio de cualidad, de mortal y corruptible en inmortal e incorruptible». Cf. A. Orbe, Antropología..., 120 , nota 8 .

94 Cf. V,2,2-3.
} 
El principio de solidaridad con la salus carnis exige la conservación del mundo donde vivirán sus moradores: si ellos terrenos, ella también terrena ${ }^{95}$. La tierra renovada es el escenario donde ha sido plantada la Iglesia por la comunión entre la Jerusalén celestial y la terrena $(\mathrm{V}, 35$, 2). La substancia (mundo) permanece, lo que cambia es la cualidad ${ }^{96}$. Se señala así una transfiguración ( $\mu \varepsilon \tau \alpha \sigma \chi \eta \mu \alpha \tau \imath \sigma \mu o ́ \varsigma)$ cósmica en la etapa final, análogamente a lo que sucede con el hombre ${ }^{97}$. Ireneo concibe, en definitiva, esta transformación del mundo como liberación del pecado y como mundo incorruptible ${ }^{98}$. En definitiva, para el santo de Lyon la capacidad de no envejecimiento y de inmortalidad proviene del vigor del Espíritu Santo (cf. V, 12, 1-2) «... que siempre hace rejuvenecer (iuvenesco) al mismo vaso en el que está» (III, 24, 1). Por esta razón el cosmos es rejuvenecido por el Espíritu de Dios para contener a la Iglesia.

En la fase final la Jerusalén celestial ataviada con ornamentos esponsales desciende sobre la tierra nueva estableciendo el tabernáculo donde Dios habitará definitivamente con los hombres. El recurso a la metáfora matrimonial que hace el obispo de Lyon es para indicar la íntima unión entre la esposa (Jerusalén celeste) y el esposo (la carne de Cristo y de los justos) realizada por el Espíritu de Dios (cf. V, 9, 4). El abrazo con características matrimoniales ha alcanzado aquí su máxima expresión. San Ireneo contempla aquí las bodas escatológicas. La consumación de los tiempos se da en la conjunción de lo terrestre con lo divino en la final inhabitación divina en lo terreno y por lo tanto enclavado en el mundo. Así la Iglesia es habitación definitiva de Dios con los hombres donde son deificados completamente. La imagen continente adquiere su brillo en plenitud, porque destellan los adornos nupciales como expresión externa de lo que dentro del tabernáculo se ha producido entre lo material y espiritual: la comunión de lo celestial con lo terrenal.

La resurrección de los justos es la culminación lógica de los presupuestos puestos por San Ireneo a lo largo de toda su obra. La salus carnis alcanza su plenitud en la coronación de la Iglesia como lugar del Espíritu que abraza a la nueva humanidad y al mundo nuevo en las bodas de la Jerusalén celestial con la terrena. El Espíritu Santo, mano del Padre,

\footnotetext{
95 Cf. A. Orbe Teología de San Ireneo III..., 557.

96 Cf. V,10,2.

${ }^{9}$ Cf. V,13,3.

98 Cf. A. Orbe, Teología de San Ireneo III..., 564.
} 
abraza en un gesto esponsal a la carne, y la determina de esa manera en un contacto íntimo: por dentro y por fuera, en una profunda comunión, que la transfigura completamente. La cualificación de la Iglesia se va dando en un proceso progresivo desde las arras hasta la resurrección final. La carne es donde brilla la acción del Espíritu Santo que la adorna y la conduce a la herencia eterna.

La confluencia de la transfiguración del elemento antropológico y cosmológico permite descubrir una implicancia eclesiológica: la Iglesia es transfigurada por el Espíritu en la consumación de los tiempos.

\section{Conclusión}

Arribamos a las siguientes ideas que confluyen en una caracterización de la relación Iglesia-Espíritu Santo y sus implicancias en la obra del obispo de Lyon.

En el contexto de la bondad inenarrable de Dios para con la humanidad (cf. IV.20, 5) se da la relación Iglesia-Espíritu Santo. Esa bondad se expresa a través de la economía salvifica por la cual Dios asiste al género humano desde el comienzo hasta el final de la historia a través de las distintas disposiciones (cf. III, 12, 13). Así, la Iglesia se convierte en una de las disposiciones divinas a través de la cual el Espíritu Santo capacita a los hombres para alcanzar la misma vida de Dios (deificación o divinización).

La realidad eclesial atraviesa todo el proyecto salvífico manifestando una dinámica progresiva y unitaria. Progresiva en cuanto que en este proceso se da una participación del Espíritu que va de la parte al todo (Espíritu profético-Espíritu de adopción-Gracia universal del Espíritu). Unitaria en la medida que se mantiene el mismo sujeto eclesial en las distintas etapas de la historia de salvación. Es el mismo Espíritu Santo el que se va manifestando y operando en el ser eclesial tanto en el Antiguo Testamento, como en el Nuevo Testamento y la consumación final.

La Iglesia es preformada en el Antiguo Testamento. Allí la humanidad se prepara para recibir la plenitud del Espíritu Santo. Pero ya se realiza una unión por adelantado con el Espíritu Santo a través de los gestos de los patriarcas y profetas. Luego en el Nuevo Testamento, la Iglesia adquiere su expresión más íntegra como depositaria del Don de Dios en su seno y aparece en una actitud de servicio a la humanidad del 
mundo entero. Finalmente en la consumación escatológica la Iglesia por una efusión universal del Espíritu será transfigurada adquiriendo la vida eterna.

Por lo tanto la Iglesia en su consideración pneumatológica es expresión del amor de Dios para con el género humano que acompaña toda su historia y su estar en el mundo. El ser eclesial crece progresivamente manteniendo su carácter unitario por la acción del Espíritu. En este desarrollo dinámico sobresalen las siguientes características:

a) Universalidad. El santo obispo utiliza los siguientes términos como conceptos equivalentes: «toda la tierra», «los gentiles», "todas las razas y naciones», «todo el género humano», «toda carne», «todo el mundo». Esas expresiones indican un pensamiento omniabarcante de toda la realidad como destinataria de la acción del Espíritu Santo. El Espíritu Santo al unirse a la carne de Cristo se une a toda carne (elemento cristológico). Toda la humanidad (elemento antropológico) es concebida como sujeto universal del derramamiento del Espíritu divino. Todo el mundo (elemento cosmológico y geográfico) se convierte en escenario receptor de la operación divina. De allí que la relación Iglesia-Espíritu Santo supone un ofrecimiento universal para todos los hombres. Pero siempre dependiendo de la libertad humana de aceptar la acción divina en su ser. También, cabría pensar la posibilidad de una realidad eclesial presente más allá de la estructuración visible de la Iglesia. Pero Ireneo sin negarlo, no ahonda en ese sentido, sino simplemente afirma que «donde está la Iglesia allí está el Espiritu de Dios y donde está el Espiritu de Dios ahi está la Iglesia y toda gracia, ya que el Espiritu es la verdad» (III, 24, 1). A partir de esa frase se establece la necesaria conexión con factores visibles (Tradición y Regla de fe) que garanticen la correcta concepción de la verdad (elemento gnoseológico).

b) Esponsalidad. El concepto comunión esponsal expresa el hecho mismo de la relación Iglesia-Espíritu Santo. El obispo de Lyon utiliza verbos con distintos matices que permiten un acercamiento a esa idea: «mezclar», «unir», «rodear», «abrazar», «deleitar», «tomar esposo». La mayoría de esas expresiones manifiestan el carácter nupcial del amor de los esposos. A partir de ellas, el lugdunense, va mostrando un desarrollo progresivo que permite un crecimiento y profundización en la conceptualización del encuentro del Espíritu con la carne. La 
posesión del Espíritu (esposo) hace que el sujeto eclesial (esposa) vaya tomando las características de aquel al que está unido en una realidad de honda intimidad: santificación. La comunión entre la Iglesia y el Espíritu comienza como una preparación en el Antiguo Testamento. Adquiere el carácter de arras en el Nuevo Testamento. Y por último, en el tiempo final, alcanzará su consumación plena por la universal gracia del Espíritu en las nupcias definitivas. Además, nuestro autor escoge algunas imágenes táctiles para expresar un verdadero contacto entre lo divino y lo humano. Las«manos de Dios» son las protagonistas de la acción plasmadora de la Iglesia. La «unción» del Verbo encarnado es compartida con todos sus discípulos para que reciban la salvación: sinónimo de la posesión del Espíritu Santo. Detrás de la unción esta la idea del óleo que no solo toca sino que penetra las superficies. El «baño bautismal» habilita para la visión de Dios. El agua no solo moja externamente sino que humedece internamente. El «injerto del olivo» muestra la realidad de la transformación interior operada por el Espíritu. Y el «abrazo» que va absorbiendo la mortalidad de la carne para conceder la incorruptibilidad manifiesta un carácter unitivo y transfigurante. La utilización de estas imágenes de contacto manifiesta el aprecio que Ireneo tiene por la carne (realidad material). Son el testimonio de lo que significa el involucrase profundamente con la carne-materia para su salvación. Entonces, para el santo lionés, el elemento eclesiológico desde su perspectiva pneumatológica supone una penetración total y transformadora del ser eclesial por el Espíritu Divino.

c) Vivificación. Para San Ireneo la relación Iglesia-Espíritu Santo desencadena un proceso de vida nueva engendrando hijos de Dios. La misma vida divina como don se comunica progresivamente al sujeto eclesial. La calidad de esa vida consiste en su unidad e incorruptibilidad. De allí que se pueda lograr la unión con Dios y también la unidad entre los miembros del cuerpo eclesial. De esa forma se convierte la Iglesia en dadora del Espíritu, Don de Dios. Pero esa relación se da en un contexto bien concreto: la Iglesia se encuentra plantada en el mundo y así se manifiesta su dimensión visible. Entonces la comunidad eclesial actuada por el Espíritu Santo se convierte en servidora de la humanidad entera. El dinamismo vivificador se comparte a través de los mismos carismas recibidos. La predicación de la Iglesia es oferta de salvación universal como la luz que porta un candelabro 
e ilumina a su alrededor. La Iglesia es el albergue hospitalario donde se continúa la acción restauradora del Espíritu que permite a los hombres fructificar para la eternidad. La Iglesia también, en medio del mundo, sufre embates y dificultades. Entonces ella persevera firme como una columna de sal. Se convierte así en un refugio seguro frente a los peligros de los errores que la asechan. Por lo tanto, la relación eclesial-pneumática confiere una riqueza vital inagotable en el contexto en el que se halla enclavada.

d) Receptáculo del Espíritu. El obispo de Lyon piensa el modo de la relación Iglesia-Espíritu Santo según la manera que se puede establecer entre el continente y el contenido. La Iglesia es un «rico receptáculo» que contiene al Espíritu de Dios ya sea como «tabernáculo» o como «vaso valioso». Por una parte, esas imágenes permiten un acercamiento plástico a una realidad tangible que es expresión terrena y visible de otra realidad celestial e invisible. A su vez, muestran una dimensión mediadora ya que los hombres se ponen en contacto con Dios a través del continente. Por otra parte, se destaca el valor de lo contenido ya que es custodiado como un rico tesoro. A su vez, el contenido posee la capacidad de cualificar con su propias características al continente hasta que se vuelva y transforme en divino (momento final de la deificación). En definitiva, para Ireneo la relación continentecontenido desde la perspectiva eclesial pneumatológica configura a la Iglesia como portadora del Espíritu.

Es indudable que para el pensamiento del obispo de Lyon es central la consideración de la relación Iglesia-Espíritu Santo como una respuesta a los desafíos que planteaba la eclesiología gnóstica de la época. Frente a una Iglesia espiritual predeterminada, secreta, elitista y ajena a las realidades materiales (mundo) el lugdunense desarrolla de la mano de su antropología y cristología una rica y vital eclesiología pneumática en el marco de la economía salvífica.

Para terminar, intentamos esbozar en una imagen sintética lo que San Ireneo de Lyon entiende después de habernos aproximado a la relación Iglesia-Espíritu Santo. La Iglesia es la portadora del abrazo esponsal y vivificador del Espíritu Santo en medio del mundo, ofreciéndose como un don a toda la humanidad. 
Resumen: En este trabajo se descubre cómo las afirmaciones de San Ireneo siguen sugiriendo claves para entender la relación Iglesia-Espíritu Santo. Se responde a la pregunta que plantea qué significa pensar una Iglesia actuada por el Espíritu Santo. En la economía veterotestamentaria se observa a la Iglesia que se prepara para recibir al Espíritu Santo. En el Nuevo testamento la Iglesia se plasma por las «manos de Dios» y es como un "vaso del Espíritu». Se encuentra diseminada y plantada en todo el mundo. La Iglesia aparece como el receptáculo de los carismas que custodia la verdad de la fe y cuya máxima expresión es el martirio. Por último, en la economía escatológica: la Iglesia transfigurada por el Espíritu. Se llega a concluir que la Iglesia es la portadora del abrazo esponsal y vivificador del Espíritu Santo en medio del mundo, ofreciéndose como un don a toda la humanidad.

Palabras clave: Ireneo de Lyon, pneumatología, eclesiología, Espíritu Santo, iglesia, abrazo, universalidad, economía de salvación.

Abstract: In this article it is discovered how the affirmations of Saint Irenaeus continue to provide clues toward understanding the relationship between the Church and the Holy Spirit. It answers Irenaues's question of what it means to think of a Church driven by the Holy Spirit. In the Old Testament economy, one observes the Church preparing to receive the Holy Spirit. In the New Testament, the Church is expressed by the "hands of God" and is a "vessel of the Spirit." It is scattered and sown worldwide. The Church appears as the receptacle of the charismata that guards the truth of faith and whose highest expression is martyrdom. Finally, in the eschatological economy, the Church is transfigured by the Holy Spirit. The conclusion that is reached here suggests that the Church is the bearer of the spousal and life-giving embrace of the Holy Spirit in the midst of the world, offered as a gift to all mankind.

Keywords: Irenaeus of Lyons, pneumatology, ecclesiology, Holy Spirit, church, embrace, universality, economy of salvation. 
